\title{
Luft og kjærlighet
}

Det heter seg at man kan leve på luft og kjærlighet. I en artikkel fra 1917 så man på hvordan luftforholdene virket inn på «det snart av-, snart tiltagende antal egteskaper» i Kristiania (Tidsskr Nor Lægeforen 1917; 37: 77-81). Man var ikke i tvil om at temperaturforholdene spilte inn.

\section{Omkring Genius epidemicus.}

2. Lufttemperaturen og egteskaperne. Av A. Magelsen, Kristiania.

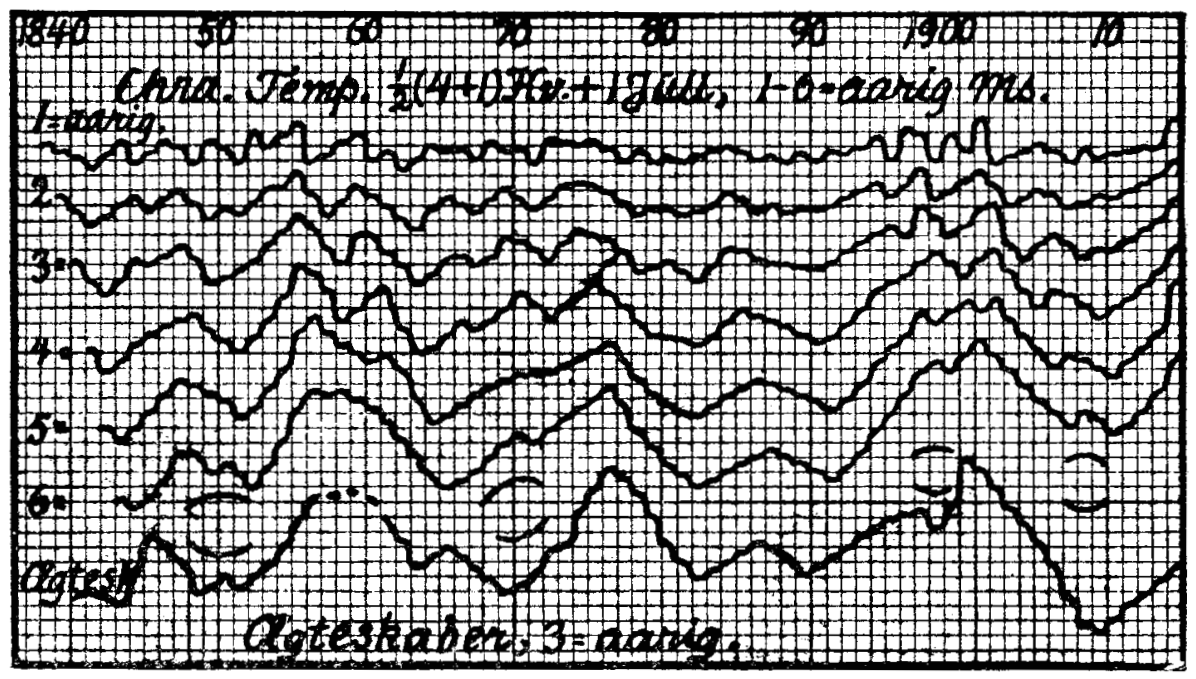

Egteskapernes vekslende mængde staar rimeligvis i nær forbindelse med befolkningens forskjellige økonomiske tilstand; denne igjen for en del med aarsveksten, som atter for størstedelen betinges av veirliget. Flere statistikere har saaledes fundet, at egteskaperne avhænger av kornpriserne. (...) Men dette er ikke tilfælde; kurverne har for hver enkelt hovedstad ganske forskjellige typer og kulminationspunkter. Heller ikke kan man tænke sig, at de «gode tider» i en større by er avhængig av vedk. bys lufttemperatur. Naar allikevel lufttemperaturen, som vi skal se, viser sig at være det (transscendentale?) mellemledd, hvis kurve stemmer overens med egteskapernes, saa ligger den formodning nær, at lignende over og om oss værende kræfter, som paavirker vitaliteten med hensyn til sygdom og død, også virker likeoverfor egteskaperne.

(...) Istedenfor nærmere at beskrive fremgangsmaaten og at avtrykke de mange og lange talrækker kan man lettere følge beregningens virkning paa utgangspunktet og dens resultat ved at betragte hosstaaende tegning, fig. 8. Den nederste kurvelinje viser egteskapernes svingninger i Kristiania i samme tidsrum. Det vil av denne tegning bl.a. fremgaa, hvorfor man ikke tidligere har kunnet tænke sig nogen forbindelse mellem egteskap og temperatur. Den 1-aarige temperaturkurve viser nemlig ingen likhet med egteskapernes, mens man ved den 6-aarige uten vanskelighet erkjender den lovmæssige sammenhæng. 